\title{
sciendo
}

Folia Oeconomica Stetinensia

Volume 20 (2020) Issue 2

DOI: $10.2478 /$ foli-2020-0042
WYDZIAL NAUK EKONOMICZNYCH I ZARZADZZANIA

\section{INNOVATION ACTIVITY AND ITS SOURCES IN INDUSTRY \\ IN THE WEST POMERANIA PROVINCE}

\author{
Jadwiga Gorączkowska, Ph.D. \\ Universtity of Zielona Góra \\ Faculty of Economics and Management \\ Institute of Economics and Finance \\ Division of Innovation and Entrepreneurship \\ Podgórna 50, 65-246 Zielona Góra, Poland \\ e-mail:j.goraczkowska@wez.uz.zgora.pl \\ ORCID: 0000-0001-6394-463X
}

Received 5 December 2019, Accepted 15 September 2020

\begin{abstract}
Research background: Innovation activities, especially the implementation of new products and processes are desirable phenomena in economic development. For this reason, phenomena that contribute to the implementation of new solutions in enterprises should be identified. These include sources of innovation activity.

Purpose: The main purpose of the article is to identify those sources of innovation activity that significantly affect product and process innovation.

Research methodology: The research of the impact of sources of ideas and information for innovation on the implementation of product and process innovations was conducted in 2018 for the period 2015-2017 in the West Pomerania Province. The study was representative. It was attended by 270 entrepreneurs whose business profile corresponds to section C PKD (Polish Business Classification) - manufacturing. Logit modeling was used in the study.

Results: As a result of the analyses it was noticed that in the region the implementation of process innovations was significantly influenced by foreign R\&D centres, suppliers (but only when entrepreneurs began to cooperate with them), as well as by conferences, fairs and exhibitions. In the case of product innovations, internal resources were included in this group.

Novelty: In the analyzed region, no advanced econometric analysis of the impact of sources of innovative activity on product and process innovations that would be representative was carried out.
\end{abstract}

Keywords: innovation activity, product innovation, process innovation, sources of innovation, industry

JEL classification: $\mathrm{O} 31, \mathrm{O} 32, \mathrm{O} 33$ 


\section{Introduction}

Innovation activities, especially the implementation of new products and processes are desirable phenomena in economic development. They enable the relative development of societies and the improvement of the condition of the national economy when compared with other countries. On the one hand, innovation activity requires stimulation through a properly selected innovation policy; on the other hand, entrepreneurs themselves are looking for various sources of ideas and information for innovation.

There are many sources of ideas and information for innovation in the economy that can contribute to the implementation of product and process innovations. The general breakdown ranking sources according to the degree of payment and availability of knowledge is interesting. Open information sources provide openly available information that does not require the purchase of technology or intellectual property rights, or interaction with the source. Acquisition of knowledge and technology results from purchases of external knowledge and capital goods (machinery, equipment, software) and services embodied with new knowledge or technology that do not involve interaction with the source. Innovation co-operation requires active cooperation with other firms or public research institutions on innovation activities (and may include purchases of knowledge and technology) (OECD, Eurostat, 2005, p. 20).

Open information sources include all forms of internal sources. In the context of building a competitive advantage, especially in entities using high and medium-high manufacturing techniques, a company's own research and development department seems to be important in implementing innovations (Schot, Steinmueller, 2018; Pieri, Vecchi, Venturini, 2018). Even if the enterprise does not have them, its employees are a significant source of innovation. In the implementation of product innovations, employees who have experience on the international market (e.g., they were previously active outside the country) and operate in national business networks play a special role (Bai, Johanson, Martin, 2019).

An important group of sources of knowledge about innovation are other enterprises. This applies to suppliers, customers and competitors. For example, there is an increase in innovation in enterprises that have found a new supplier of components or a recipient of their products (Medhi, Jain, Jain, (2019). Despite these benefits, it should be emphasized that increasing competition is forcing entrepreneurs to seek new knowledge in other external sources, e.g., in start-ups with which it has not cooperated so far, and which allows identifying ideas with a higher degree of novelty than in the case of suppliers themselves (Homfeldt, Rese, Simon, 2019). 
Customers are an extremely valuable source of information for innovation, but they need to be properly encouraged to share knowledge about products. In this process there are variables such as affiliation (loyalties to a brand), specialist knowledge, expression and experience (the ability to be creative), recognition (public acknowledgment of a person's status and/or achievements), community and tangible reward (Palma, Trimi, Hong, Serv Bus, 2019). Particularly creative in generating the commercially most promising concepts are the so-called lead users. They feel unmet needs that will spread to the rest of the market months or years later (Hamdi-Kidar, Keinz, Le Nagard, Vernette, 2019).

In developing economies, it can be particularly effective to bring new knowledge from countries with higher technological advancement. This is a desirable phenomenon, because the search for new knowledge abroad, in particular from the business sector rather than from universities or research institutions causes the implementation of radical product innovations (Tojeiro-Rivero, Moreno, Badillo, 2019).

Due to the specifics of functioning not only in Poland but also in the world of science entities and especially public entities, cooperation among such entities is less than among commercial enterprises themselves. The results suggest that both individual and combined use of external scientific and market knowledge are positively and significantly associated with inventors' quantity and quality of inventions (Scandura, 2019). For this reason, efforts should be made to stimulate the search for knowledge in the field of science.

Each of the above-mentioned sources of innovation may have a positive impact on innovation activities. Currently, the combination of several sources is becoming increasingly important, e.g., knowledge from private and public sectors clients as well as competitors (Basit, Medase, 2019). However, the use of external knowledge is better the better the knowledge flows in intra-organizational networks (Yu, Chen, 2019). For this reason, entrepreneurs should not neglect the organizational aspects of implemented innovations.

Considering the above considerations, a question arises as to how effective it is to search for new knowledge both within and outside enterprises. Does the fact that some sources are widely available (e.g., knowledge hidden inside companies) and are used by many entities mean that it clearly contribute to creating product innovations and process implementation? The aim of the article is therefore to identify such sources of ideas and information for innovation that significantly affect product and process innovation in the studied region. Logit modeling was used in the analyzes. The research hypothesis is that the innovation activity of enterprises depends on a number of resources, while the use of any individual resources by many entrepreneurs is not indicative of a significant impact on the innovation of the region. 
The remainder of the article is divided into four subsections. The first presents the most important research results related to the use of various sources of innovation activity by enterprises. The second discusses the research method (logit modeling and selection of variables) and characteristics of the research sample (industrial enterprises in the West Pomerania Province). The third section presents multi-factor logit models that illustrate how sources influence the implementation of product and process innovations. Then, the presented analyses are summarized and compared with the results of similar research conducted by other scientists.

\section{Characteristics of the research sample and method of the research}

The research of the relationship between sources of innovative activity and implemented product and process innovations was carried out in 2018 for 2015-2017. The three-year research period results from the methodological standards related to the study of innovative activity recommended by the OECD contained in the Oslo Manual (OECD, Eurostat, 2018).

The study was representative on section C Polish Business Classification (PKD; Polska Klasyfikacja Działalności) - manufacturing. The population consisted of 15,828 entities. From this group over 4,000 entities were drawn, of which 329 completed the survey forms (sampling error was $6 \%$ ).

Among the surveyed enterprises, the largest group were micro entities (over 65\%). 25\% of the surveyed entities are small, with slightly over $7 \%$ being medium-sized enterprises. There were only 8 large entities in the sample $(2 \%)$.

Table 1. Structure of the studied companies in terms of the size of classes

\begin{tabular}{|l|c|c|}
\hline \multicolumn{1}{|c|}{ Size classes } & Quantity of companies & Percentage \\
\hline Micro & 214 & 65.1 \\
\hline Small & 83 & 25.2 \\
\hline Medium-sized & 24 & 7.3 \\
\hline Large & 8 & 2.4 \\
\hline Sum & 329 & 100.0 \\
\hline
\end{tabular}

Source: own elaboration.

Product and process innovations were analysed as dependent variables. Product innovations include new or significantly improved products that have been introduced to the market. In the 
process innovations there were introduced new production methods, production-related systems and support systems.

Sources of ideas and information for innovation were adopted as independent variables. Among the entities which the entrepreneurs indicated as sources and with which it was possible to establish cooperation, it was checked whether cooperation occurred. In this way, it was possible to identify whether innovation activity is only affected by passive observation of other entities, or whether cooperation between them is necessary. Sources of innovation activity are divided into the following groups:

a) internal resources;

b) business enterprises:

- suppliers, including Cooperation with suppliers,

- customers/recipients, including cooperation with recipients,

- competitors, including cooperation with competitors;

c) science research sector:

- Polish Academy of Sciences departments, including cooperation with the Polish Academy of Sciences departments,

- National R\&D centres, including cooperation with national R\&D centres,

- Foreign R\&D centres, including cooperation with foreign R\&D centres,

- Higher education institutions, including cooperation with higher education institutions;

d) other sources:

- professional conferences, meetings, fairs and exhibitions,

- branch literature and journals,

- scientific and technical associations.

Logit modeling was used in the process of defining the impact of sources of ideas and information for innovation on the implementation of product and process innovations. The choice of the research method was determined by the dichotomous nature of the variables adopted for the study. Respondents' answers were assigned a value of 1 when they answered yes to the question in the survey, e.g., they implemented a product innovation or when they used the analyzed source of innovation activity, and 0 when they did not.

Generally speaking logistic regression is a mathematical model which can be used to describe the influence of several variables $X_{1}, X_{2}, \ldots, X_{k}$ on the dichotomous variable $Y$. If all independent variables are qualitative, the model of logistical regression is equivalent to the loglinear model (Świadek, 2011). The logistic function takes values from 0 to 1 , so it can describe 
probability values that are always in this range (Stanisz, 2007). In the case of the conducted survey, they will determine the odds of innovation activity occurring in enterprises in the West Pomerania Province.

In the logit model probability is expressed with the help of odds. Probability is expressed with the number of successes in relation to the number of attempts, while the odds are expressed by the number of successes in relation to the number of failures (Danieluk, 2010). In the conducted study two groups of enterprises were compared with each other - those that used the analysed sources of innovation activity and those that did not. Therefore, the odds ratios of two observation classes, i.e., those using a given source and those not doing so, can be compared. The odds ratio indicates the relation that a given event (e.g., creation of a new product) will be in the first group of entities (e.g., in enterprises seeking new knowledge from suppliers) in relation to the fact that it will also be in the second (e.g., in the group of entities who are not seeking new knowledge from suppliers). They are written using the formula (Stanisz, 2007):

$$
\text { OddsRatio }=\frac{p_{1}}{1-p_{1}} \frac{1-p_{2}}{p_{2}}=\frac{p_{1}\left(1-p_{2}\right)}{p_{2}\left(1-p_{1}\right)}
$$

Values of the odds ratio are interpreted as follows:

a) OddsRatio $>1$ - in the first group occurrence of the event is highly likely;

b) OddsRatio $<1$ - in the first group occurrence of the event is less likely;

c) OddsRatio $=1-$ in both classes of observation the event is equally likely.

The process of estimating models took place in two stages in Statistica software. In the first stage, using the Interactive Model Builder tool, the independent variables (sources of innovative activity) were distinguished, and this had a significant impact on the dependent variable (implemented product or process innovations). In the second stage, logit models were estimated illustrating the impact of sources of ideas and information for innovation on the two analysed attributes of innovative activity. The article presents the values of the odds ratios that meet the conditions of statistical significance along with their basic statistics.

\section{The influence of sources of ideas and information for innovation on innovation activity}

In the West Pomerania Province, entrepreneurs have used a wide variety of sources of ideas and information in the search for innovation. A significant role in this endeavor was played by internal resources and business enterprises. The potential of the enterprise's own resources was used by over $40 \%$ of the surveyed entities. The search for new knowledge among suppliers 
was at a similar level. It is important to note that in over $13 \%$ of cases the source was used in the best possible way, i.e., as co-operation with a partner. The majority of enterprises treated their clients and recipients as a source of innovation (over $60 \%$ ). Over $10 \%$ of entities from this group created new products together with customers. A quarter of the research sample sought knowledge from competitors. Innovative cooperation was established in nearly $2 \%$ of cases in this group.

Searching for new knowledge in the realm of science was less popular than from enterprises. From this science focused group entrepreneurs used universities as a source of innovation most often (nearly $8 \%$ of the sample). In nine cases cooperation with this institution was established. Over $4 \%$ of the surveyed entities attempted to transfer new knowledge from foreign R\&D centers. In one case cooperation was established. Less than $3 \%$ of samples sought new knowledge in the Polish Academy of Sciences departments. Cooperation occurred in three cases. Two entities found sources of innovation in national R\&D centers.

Among other sources, nearly $26 \%$ of the surveyed enterprises sought knowledge about new solutions at conferences, fairs or exhibitions, 19\% in branch literature and journals, and over $4 \%$ in scientific and technical associations.

Table 2. Sources of ideas and information for innovation which were used in the West Pomerania Province in 2015-2017

\begin{tabular}{|c|c|c|}
\hline Sources for innovation & Number of companies & Percentage \\
\hline 1 & 2 & 3 \\
\hline Internal resources & 133 & 40.4 \\
\hline \multicolumn{3}{|l|}{ Business enterprises included } \\
\hline Suppliers, included & 138 & 41.9 \\
\hline Cooperation with suppliers' & 43 & 13.1 \\
\hline Customers/recipients, included & 201 & 61.1 \\
\hline Cooperation with recipients & 35 & 10.6 \\
\hline Competitors, included & 76 & 23.1 \\
\hline Cooperation with competitors & 6 & 1.8 \\
\hline \multicolumn{3}{|l|}{ Science research sector included } \\
\hline The Polish Academy of Sciences departments, included & 9 & 2.7 \\
\hline Cooperation with the Polish Academy of Sciences departments & 3 & 0.9 \\
\hline National R\&D centres, included & 2 & 0.6 \\
\hline Cooperation with national $\mathrm{R} \& \mathrm{D}$ centres & 0 & 0.0 \\
\hline Foreign R\&D centres, included & 14 & 4.3 \\
\hline Cooperation with foreign $\mathrm{R} \& \mathrm{D}$ centres & 1 & 0.3 \\
\hline
\end{tabular}




\begin{tabular}{|l|c|c|}
\hline \multicolumn{1}{|c|}{1} & 2 & 3 \\
\hline Higher education institutions, included & 26 & 7.9 \\
\hline Cooperation with higher education institutions & 9 & 2,7 \\
\hline Other sources & \multicolumn{2}{|c|}{} \\
\hline Conferences, fairs and exhibitions & 65 & 25.8 \\
\hline Branch literature and journals & 63 & 19.1 \\
\hline Scientific and technical associations & 14 & 4.3 \\
\hline
\end{tabular}

Source: own elaboration.

Analysing Table 2, it can be concluded that internal sources, other enterprises and other sources of information attract the greatest support for creating new products and process these sources were used by the largest number of enterprises. However, econometric analysis indicated, that not all of them met any statistical significance.

In respect of product innovations, the chances for implementing new products were mostly stimulated by foreign R\&D centres (Table 3). In entities that used this source, the chances of implementing product innovations increased more than 5.5 times compared to entities that did not seek knowledge about new products in foreign R\&D centres. The other three variables, i.e., internal resources, cooperation with suppliers, and conferences, fairs and exhibitions increased the chances of creating new products more than 2 times.

Table 3. Influence of sources of ideas and information for innovation on product innovation in the West Pomerania Province in 2015-2017

\begin{tabular}{|l|c|c|c|c|c|}
\hline \multicolumn{1}{|c|}{ Sources for innovation } & Odds ratio & Standard error & Student's t-test & p-value & chi-square \\
\hline Internal resources & 2.49 & 0.24 & 3.78 & 0.0001 & 14.29 \\
\hline Cooperation with suppliers' & 2.18 & 0.35 & 2.20 & 0.0281 & 4.82 \\
\hline Foreign R\&D centres & 5.51 & 0.68 & 2.51 & 0.0122 & 6.28 \\
\hline Conferences, fairs and exhibitions & 2.34 & 0.27 & 3.14 & 0.0017 & 9.88 \\
\hline Constants & 0.37 & 0.18 & -5.54 & 0.0000 & 30.73 \\
\hline
\end{tabular}

Source: own elaboration.

Analyzing the degree of novelty of the implemented product innovations (Table 4), it can be noticed that their implementation stimulates the use of internal sources (over 2 times) and establishing cooperation with the recipient (almost 2 times). It is important that the entities that seek new knowledge in universities less often launch products that are new to the enterprise itself. Their impact becomes significant when enterprises implement new products on a market and country scale. Entrepreneurs who were looking for new knowledge in universities and then 
started working with them nearly 5 times more often introduced new products on the scale of the market in which they operate. In the same way, product innovation was stimulated by participation in conferences, fairs and exhibitions.

Among the analyzed sources, the search for new knowledge at universities contributed to the introduction of product innovations on a national scale to the greatest extent, but only after establishing cooperation with it. After establishing cooperation, the chances increased almost six times. More than twice the chances of implementing product innovations nationwide have increased in entities that sought new knowledge at conferences, fairs and exhibitions, as well as competitors.

In the West Pomerania Province, two sources contributed to the creation of product innovations on a global scale. These were internal sources that increased the chances of introducing these innovations three times and foreign research centers, under the influence of which the chances increased more than 10 times.

Table 4. Influence of Business Support Organizations on the spectrum of novelty of product innovations in the West Pomerania Province in 2015-2017

\begin{tabular}{|c|c|c|c|c|}
\hline \multirow{2}{*}{ Sources for innovation } & \multicolumn{4}{|c|}{ Novelty for } \\
\hline & enterprise & market & country & world \\
\hline Internal resources & $2.14 *$ & & & $3.01 * * *$ \\
\hline Cooperation with suppliers' & & $3.08 * *$ & & \\
\hline Cooperation with recipients & $1.93 * * *$ & & & \\
\hline Competitors & & & $2.04 * * *$ & \\
\hline Foreign R\&D centres & & & & $10.65 * * *$ \\
\hline $\begin{array}{l}\text { Higher education } \\
\text { institutions, included }\end{array}$ & $0.23 * *$ & & & \\
\hline $\begin{array}{l}\text { Cooperation with higher } \\
\text { education institutions }\end{array}$ & & $4.60 * * *$ & $5.61 * *$ & \\
\hline $\begin{array}{l}\text { Conferences, fairs } \\
\text { and exhibitions }\end{array}$ & & $4.60 *$ & $2.56^{* *}$ & \\
\hline Constants & $0.25 *$ & $0.03 *$ & $0.05 *$ & $0.02 *$ \\
\hline Chi-square & 17.66 & 22.55 & 13.71 & 13.69 \\
\hline $\mathrm{p}$-value & 0.0005 & 0.0001 & 0.0033 & 0.0011 \\
\hline
\end{tabular}

* - statistical significance $0.01 ; * *$ - statistical significance $0.05 ; * * *$ - statistical significance 0.1 .

Source: own elaboration.

Three variables had a significant impact on the implementation of process innovations (Table 5). These were, as in the case of product innovations, foreign R\&D centres, cooperation 
with suppliers as well as conferences, fairs and exhibitions. There were no internal sources in this group.

Foreign R\&D units increased the chances of introducing new processes to enterprises more than 20-fold. In entities that sought new knowledge from suppliers with whom they cooperated, the chances of implementing new processes were more than 3 times higher than in enterprises that did not use this source. Participation in conferences, fairs or exhibitions increases the chances of implementing new processes by almost more than 2 times.

It is surprising that entities that used the services of the Polish Academy of Sciences departments were less likely to implement process innovations than companies that did not use this source. Most likely, this result was affected by a small number of enterprises that indicated departments as a source of innovation (only 9 entities) and at the same time no process innovations were implemented.

Table 5. Influence of sources of ideas and information for innovation on process innovation in the West Pomerania Province in 2015-2017

\begin{tabular}{|l|c|c|c|c|c|}
\hline \multicolumn{1}{|c|}{ Sources for innovation } & Odds ratio & Standard error & Student's t-test & p-value & chi-square \\
\hline Cooperation with suppliers' & 3.31 & 0.39 & 3.09 & 0.0020 & 9.54 \\
\hline $\begin{array}{l}\text { The Polish Academy } \\
\text { of Sciences departments }\end{array}$ & 0.18 & 0.93 & -1.86 & 0.0632 & 3.45 \\
\hline Foreign R\&D centres & 20.06 & 1.12 & 2.68 & 0.0073 & 7.21 \\
\hline $\begin{array}{l}\text { Conferences, fairs } \\
\text { and exhibitions }\end{array}$ & 2.32 & 0.27 & 3.04 & 0.0024 & 9.22 \\
\hline
\end{tabular}

Source: own elaboration.

Considering the impact of sources of innovative activity on the degree of the novelty of implemented process innovations (Table 6), it is noted that internal sources play a role in the case of new solutions for the enterprise implementing them. In entities that use them, they grow twice. There is a nearly 3 -fold increase in opportunities in this area when establishing cooperation with suppliers, and a nearly 2-fold increase in the case of participation in conferences, fairs and exhibitions.

The implementation of new processes on the scale of the market appears when enterprises establish cooperation with suppliers. This increase is quite significant, almost 4 times. The same type of source more than quadruples the chances of implementing new processes nationwide. In this case, the impact of participation in conferences, fairs and exhibitions is at a similar level. Research centers have a much larger impact. Searching for knowledge about new processes and then establishing cooperation with the Polish Academy of Sciences departments increases 
the chances of their implementation more than 15 times. On the other hand, a nearly 10 -fold increase was recorded in the studied region in entities that transferred solutions from foreign research centers.

Analyzing the impact of sources of innovative activity on individual degrees of the novelty of implemented processes, it is noticed that a higher degree of innovation novelty requires a greater participation of institutions from the sphere of science. In addition, as the degree of novelty increases, the value of the odds ratio for individual sources also increases. At the same time, no coefficients with values below one appear. This indicates the great importance of institutions from the sphere of science when creating innovation on a national and global scale.

Table 6. Influence of Business Support Organizations on the spectrum of the novelty of process innovations in the West Pomerania Province in 2015-2017

\begin{tabular}{|c|c|c|c|c|}
\hline \multirow{2}{*}{ Sources for innovation } & \multicolumn{4}{|c|}{ Novelty for } \\
\hline & enterprise & market & country & world \\
\hline Internal resources & $2.09 *$ & & & \\
\hline Cooperation with suppliers' & $2.73 *$ & $3.70 * *$ & $4.05^{*}$ & \\
\hline $\begin{array}{l}\text { Cooperation with the Polish Academy } \\
\text { of Sciences departments }\end{array}$ & & & $15.47 * * *$ & \\
\hline Foreign R\&D centres & & & $9.91 *$ & $14.05^{*}$ \\
\hline Conferences, fairs and exhibitions & $1.79 * *$ & & $3.78^{* *}$ & \\
\hline Constants & $0.38 *$ & $0.04 * *$ & $0.01 *$ & $0.02 *$ \\
\hline Chi-square & 25.51 & 5.25 & 17.23 & 8.57 \\
\hline p-value & 0.0000 & 0.0219 & 0.0018 & 0.0034 \\
\hline
\end{tabular}

* - statistical significance $0.01 ; * *$ - statistical significance $0.05 ; * * *$ - statistical significance 0.1 .

Source: own elaboration.

\section{Conclusions}

In the West Pomerania Province in 2015-2017, significant sources of innovative activity (i.e., those that really stimulated it) were foreign R\&D centres, internal resources, suppliers (but only when entrepreneurs began to cooperate with them) as well as conferences, fairs and exhibitions. At this stage of consideration, it should be emphasized that it cannot be unequivocally stated that the other sources do not affect the region's innovation activity. There is no difference in the implementation of product and process innovations between the enterprises that use them and those that do not. Nevertheless, entrepreneurs can be inspired 
by these sources and implement innovations. This is important because research carried out in South Korea (which has a highly developed economy) confirms that the implementation of product and process innovations was influenced by customers, universities and government agencies (Jeong, Chung, Roh, 2019). In this context, it would be beneficial to repeat the study in a few years, so that further development in the use of sources can be reviewed. Undoubtedly, a positive phenomenon would be a situation in which entrepreneurs were more interested in seeking knowledge about new products from science- based entities.

The largest impact, i.e., the largest increase in the chances of implementing new products, appeared in enterprises that sought new knowledge from foreign R\&D centres. The increase in chances in this case was the largest. However, when attention is paid to the fact that only $5 \%$ of enterprises used their services, it can be concluded that their impact on regional innovation is small, i.e., a positive effect concerns only a small number of entities. In this case, it can be assumed that despite lower odds ratios, better results are obtained by using internal sources or suppliers as cooperating partners, as their impact is spread over a larger number of entities.

In the studied region, it seems interesting that the mere search for new knowledge from suppliers does not significantly affect the creation of new solutions. It is only when this source becomes a cooperating partner that innovation is stimulated in the area. Cooperation may be associated with the need to improve the technical specifications of materials and components used in production. This conclusion is in line with Doloreux, Turkina, Van Assche (2019), who on the basis of research in Canada concluded that changes introduced in into new products require in this context formal cooperation with the suppliers of any components used.

In the West Pomerania Province, the number of entities that indicated other enterprises as sources of information on innovation was much larger than that of institutions from the sphere of science. At the same time, except for the implementation of new products in cooperation with suppliers, this did not translate into a much greater impact on the innovation of the surveyed enterprises. This condition can be attempted to be explained in two ways - on the one hand, entrepreneurs monitor the market situation, examine it, on the other hand, after comparing with other entities, they do not notice the need to introduce changes.

Despite this, it should be emphasized that institutions from the sphere of science play an important role in the analyzed region. This is particularly visible in the case of analyzing the degree of novelty of implemented product and process innovations. It turns out that the higher level of implemented innovation requires high participation of the science sector in their implementation. Innovations at the enterprise and market level emerge using sources related to the enterprise sector - cooperation with the supplier and recipient, and based on internal 
sources. In the case of innovations on a national or global scale, institutions from the sphere of science - universities, the Polish Academy of Sciences departments, and foreign R\&D centers - began to play an important role. In the case of product innovations, this impact was even stronger. Entities that search for new knowledge in universities less often implement new products on an enterprise scale. This proves that knowledge that can be transferred from universities and then commercialized has a large market potential.

Considering the above conclusions, it can be stated that the purpose of the article has been achieved and the research hypothesis has been confirmed. As a result of the analyzes, it turned out that the high popularity of a given source of innovative activity is not synonymous with its significant impact on the implementation of product and/or process innovations.

Innovation activity allows the region to develop. For this reason, it is in the interest of local authorities to support and stimulate it. Considering the conclusions that have emerged as a result of the study in the West Pomerania Province at the level of regional authorities, it is necessary to create pro-innovative solutions that will contribute to establishing cooperation between entrepreneurs, as well as to increase the number of entities that seek new knowledge in entities from the sphere of science, especially those outside national borders.

The analyzes allowed to achieve the article's goal and to positively verify the research hypothesis. Showing in the analyzes that the use of a given type of source of innovative activity by many enterprises is not synonymous with its large, positive impact on innovative activity. Only deeper analyzes allowed to determine whether a given type of source really stimulates innovative activity. This shows how careful a researcher should be in his/her analyzes. However, entrepreneurs are looking for new knowledge about innovations with other entrepreneurs. In the case of a well-run innovation policy at national and regional level, this will allow the creation of cooperative relationships and the joint implementation of innovation.

The conducted study has some limitations. In addition to the previously mentioned difficulties with the assessment of sources whose impact did not meet the criteria of statistical significance, there are also issues related to the diagnostic nature of the study. It allowed to determine which sources influence the implementation of process and product innovations, but it does not explain why this is so. As a result, further analyzes should be carried out in this context. 


\section{References}

Bai, W.S., Johanson, M., Martin, O.M. (2019). Dual Business Relationships, Opportunity Knowledge, and New Product Development: A Study on Returnee Young Ventures. Journal of international marketing, 27 (3), 26-42. DOI: 10.1177/1069031X19852961.

Basit, S.A., Medase, K. (2019). The diversity of knowledge sources and its impact on firmlevel innovation Evidence from Germany. European Journal of Innovation Management, 22 (4), 681-714. DOI: 10.1108/EJIM-10-2018-0232.

Brinks, V. (2019). 'And Since I Knew About the Possibilities There horizontal ellipsis': The Role of Open Creative Labs in User Innovation Processes. Tijdschrift voor Economische en Sociale Geografie, 110 (4), 381-394. DOI: 10.1111/tesg.12353.

Danieluk, B. (2010). Zastosowanie regresji logistycznej w badaniach eksperymentalnych, Psychologia społeczna, 5 (2-3 (14)), 199-216.

Doloreux, D., Turkina, E., Van Assche, A. (2019). Innovation type and external knowledge search strategies in KIBS: evidence from Canada. Service Business, 13 (3), 509-530. DOI: $10.1007 / \mathrm{s} 11628-018-00393-y$.

Hamdi-Kidar, L., Keinz, P., Le Nagard, E., Vernette, E. (2019). Comparing Lead Users to Emergent-Nature Consumers as Sources of Innovation at Early Stages of New Product Development. Journal of Product Innovation Management, 36 (5), 616-631. DOI: 10.1111/ jpim. 12500 .

Homfeldt, F., Rese, A., Simon, F. (2019). Suppliers versus start-ups: Where do better innovation ideas come from? Research policy, 48 (7), 1738-1757. DOI: 10.1016/j.respol.2019.04.002.

Jeong, S.W., Chung, J.E., Roh, J.S. (2019). Impact of External Knowledge Inflow on Product and Process Innovation of Korean SMEs: Absorptive Capacity as a Mediator. Clothing and Textiles Research Journal, 37 (4), 219-234. DOI: 10.1177/0887302X19860913.

Medhi, P.K., Jain, P., Jain, T. (2019). Effects of information sources for new customers and suppliers on the immediate innovation output of firms. European Journal of Innovation Management, 22 (4), 660-680. DOI: 10.1108/EJIM-09-2018-0202.

Palma, F.C., Trimi, S., Hong, S.G. (2019). Motivation triggers for customer participation in value co-creation. Service Business, 13 (3), 557-580. DOI: 10.1007/s11628-018-00395-w.

OECD, Eurostat (2005). Oslo Manual. Guidelines for collecting and interpreting innovation data. Third edition. The Measurement of Scientific and Technological Activities. OECD Publishing, Paris. DOI: 10.1787/9789264013100-en.

OECD, Eurostat (2018). Oslo Manual 2018. Guidelines for Collecting, Reporting and Using Data on Innovation. 4th Edition. The Measurement of Scientific, Technological and Innovation Activities. OECD Publishing, Paris/Eurostat, Luxembourg. DOI: 10.1787/9789264304604-en. 
Pieri, F., Vecchi, M., Venturini, F. (2018). Modelling the joint impact of R\&D and ICT on productivity: A frontier analysis approach. Research Policy, 47 (9), 1842-1852. DOI: 10.1016/j.respol.2018.06.013.

Scandura, A. (2019). The role of scientific and market knowledge in the inventive process: evidence from a survey of industrial inventors. The Journal of Technology Transfer, 44 (4), 1029-1069. DOI: 10.1007/s10961-017-9643-3.

Schot, J., Steinmueller, W.E. (2018). Three frames for innovation policy: R\&D, systems of innovation and transformative change. Research Policy, 47 (9), 1554-1567. DOI: 10.1016/j. respol.2018.08.011.

Stanisz, A. (2007). Przystępny kurs statystyki. Tom 2. Modele liniowe i nieliniowe. Kraków: Statsoft.

Świadek, A. (2011). Regionalne systemy innowacji w Polsce. Warszawa: Difin.

Tojeiro-Rivero, D., Moreno, R., Badillo, E.R. (2019). Radical Innovations: The Role of Knowledge Acquisition from Abroad. Review of Industrial Organization, 55 (2), 173-207. DOI: 10.1007/s11151-018-9659-3.

Yu, S.H., Chen, H.C. (2019). External knowledge, intraorganisational networks and exploratory innovation: an empirical examination. Innovation-Organization \& Management, Early Access. DOI: 10.1080/14479338.2019.1642764. 